\title{
Bibliometric Analysis of Scientific Production on Tourism and Tourism Product
}

\author{
Norton Peña Aguilera ${ }^{1}$, Lisbet Eunice Pérez Anzardo ${ }^{1}$, Pedro Bruzón Sosa ${ }^{1}$, \\ Reyner Pérez Campdesuñer ${ }^{2}$ \\ ${ }^{1}$ Teaching Department of the Municipal University Branch Calixto García, University of Holguín, Holguín, Cuba \\ ${ }^{2}$ Tourist Departament of Technical University of Ecuador, Santo Domingo, Ecuador
}

\section{Email address:}

npena@uho.edu.cu(N. P. Aguilera), lepereza@uho.edu.cu(L. E. P. Anzardo),pbruzons@uho.edu.cu(P.B. Sosa), rfperezcampdesuner@gmail.com (R.P.Campdesuñer)

\section{To cite this article:}

Norton Peña Aguilera, Lisbet Eunice Pérez Anzardo, Pedro Bruzón Sosa, Reyner Pérez Campdesuñer. Bibliometric Analysis of Scientific Production on Tourism and Tourism Product. International Journal of Hospitality \& Tourism Management. Vol. 3, No. 1, 2019 , pp. 1-8. doi: $10.11648 /$ j.ijhtm.20190301.11

Received: November 13, 2018; Accepted: December 17, 2018; Published: February 21, 2019

\begin{abstract}
Tourism is one of the sectors with more dynamism in the world. For the Latin American countries it represents an opportunity of growth and economic and social development. Cuba is making its best efforts to link and base its economy to this ever-growing field. The presently article carried out a bibliometric analysis of the scientific investigations about tourism in general and on the tourist product, starting from the year 1975. That scientific production was formally and thematically characterized through several bibliometric indicative, standing out the productivity for authors, the chronological variation of the number of works published in this field, idiomatic productivity, the areas in those that they have been carried out, among other elements of interest for this study type. The objective is to verify what is being investigated, and for who, as well as the evolution of the academic expression of the countries in this area, in articles and magazines scientific, which are the main channel of diffusion of this topic at the present time, among other publications which contribute to a better knowledge of the map of the investigation. The analysis presented indications of improvements in the academic participation, what represents the importance of the topic for studies of sustainable tourism and the growth of the sector.
\end{abstract}

Keywords: Bibliometrics, Scientific Investigation, Tourism and Tourism Product

\section{Introduction}

Tourism constitutes one of the social economic phenomenon of more importance and of quicker growth at world level, due to this, it has caused a daily bigger order in the tourist products that are demanded and the movement of tourists toward alternative forms, in those that are prioritized with more clarity the social responsibility for the protection of the natural, historical and cultural values of the destination.

All design of tourist products should be considered as an artistic, original work, with the following objectives: economic, social and environmental profitability, and the satisfaction of the demand [1]. Specialists of the marketing [2-5] have outlined adaptive procedures to the design of tourist products, although they have little integration level among the agents of the destination. More recent authors [6-
9] incorporate new perspectives that favor the design of integrated tourist products.

The modernized works in several authors are recognized [10-14] that structure the taxonomy of the tourist products or they approach diverse angles applying knowledge of several areas of the science.

The purpose of this study is to deepen in this topic and carried out a bibliometric analysis because it has become a fundamental instrument of support to the administration of the scientific and technological policies in the developed countries.

Bibliometrics takes charge of the study of quantitative aspects of production and dissemination and use of registered information and mathematical procedures that are good to make foreshadow and to make decisions around such processes [15].

The indicators have special importance in the metric 
studies. Each study uses a sequence of particular indicators. Of their selection depends, in great measure, the quality and the impact of the final investigation. They provide quantitative and objective information on the investigation process results, their volume, evolution; visibility and structure [16]. The inquiries of this investigation will be useful for the decisions in the area of future investigations and contribute for strategies bases in favor of the sustainable development of the tourist sector.

\section{Development}

With the purpose of identifying the investigations about the competitiveness in the tourist environment, the electronic database of SciVerse Scopus was consulted, attributable to that it is the biggest database of summaries and literature appointments revised anonymously and available in webs of quality, containing from all over the world near 18.000 titles of 5.000 editorials. The main particularity is that it is not limited to the recount of the appointments that a publication obtains, but it also considers the importance or influence of the appointments according to the significance of the magazine of which they come.

Some selection approaches were pre-established for the realization of this investigation, such as: year of publication, thematic about tourism, publication in international magazines, among others. The results are presented with the use of descriptive statistic in graphics and charts structure.
According to carried out studies and in accordance with the report of the database of SCimago Journal Ranking, that is a ranking of magazines elaborated from the database Scopusen function of the impact index SJR; exists a total of 101 magazines that publish topics on the tourist administration. Of them:

53 of the United Kingdom.

30 of the United States.

4 of Holland.

2 of Croacia.

2 of Serbian.

2 of Germany.

1 Ireland, Iran, South Africa, Greece, Switzerland, Eslovenia, Spain and Bulgaria.

SJR has been elaborated by the Scimago Research Group, an investigation group of the Superior Council of Scientific Investigations (CSIC) and the Universities of Granada, Carlos III, of Extremadura, Alcalá de Henares and Oporto, guided by Félix de Moya Anegón. The SJR is the result of an agreement among the Scimago Research Group and Elsevier-Scopus. It is an index with Spanish origins, but recognized universally.

The results obtained on the thematic of the Tourism per year are shown. It is evidenced that it was from 1975 that they began to publish documents that approach the topic. Since the year 2011 there are more than 4 thousand documents that evaluate the matter, being the years 2016 and 2017 those of more productivity. (Figure 1)

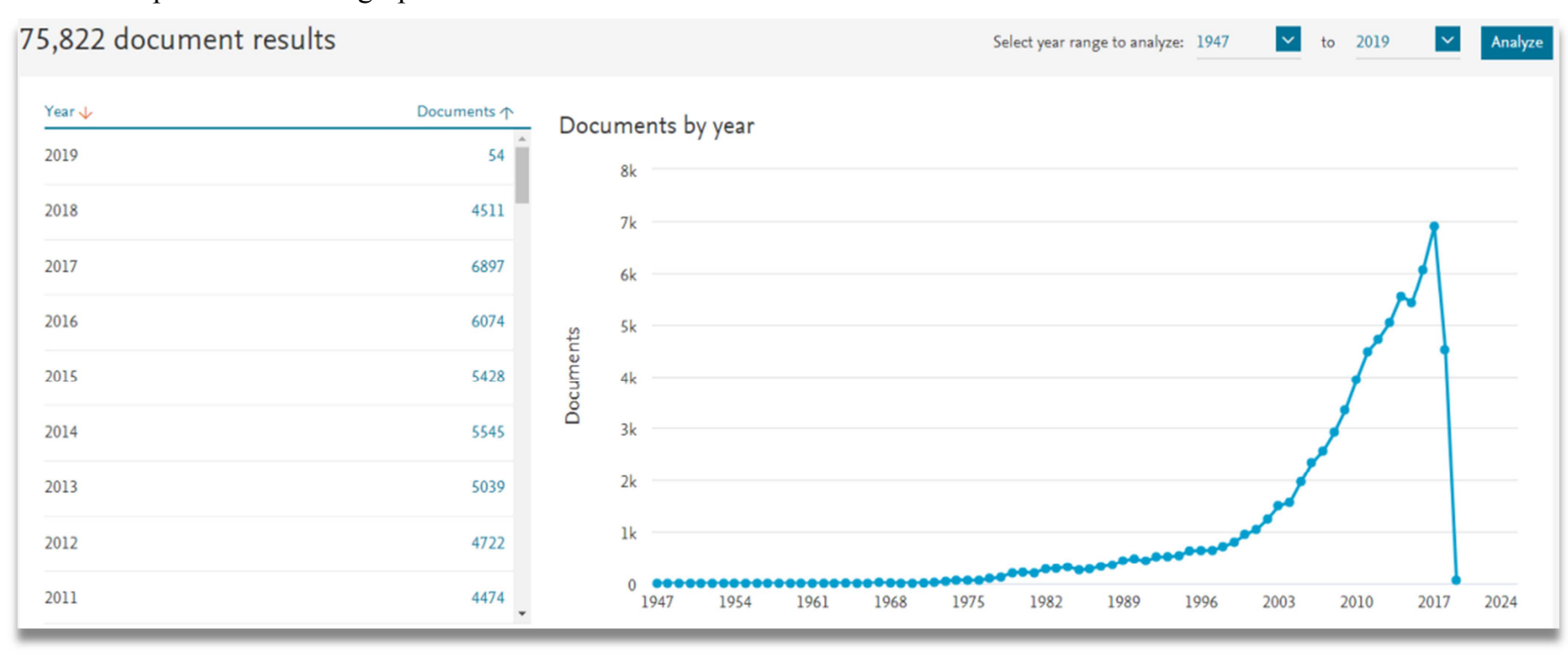

Figure 1. Number of publications a year.

The areas that stand out more are the Social Sciences with 36001 documents which represents $23.7 \%$, those of Business, administration and accounting with 31647 documents, representing $23.7 \%$ and the environmental Science with 15196 documents, representing $11.4 \%$. (Figure 2) 


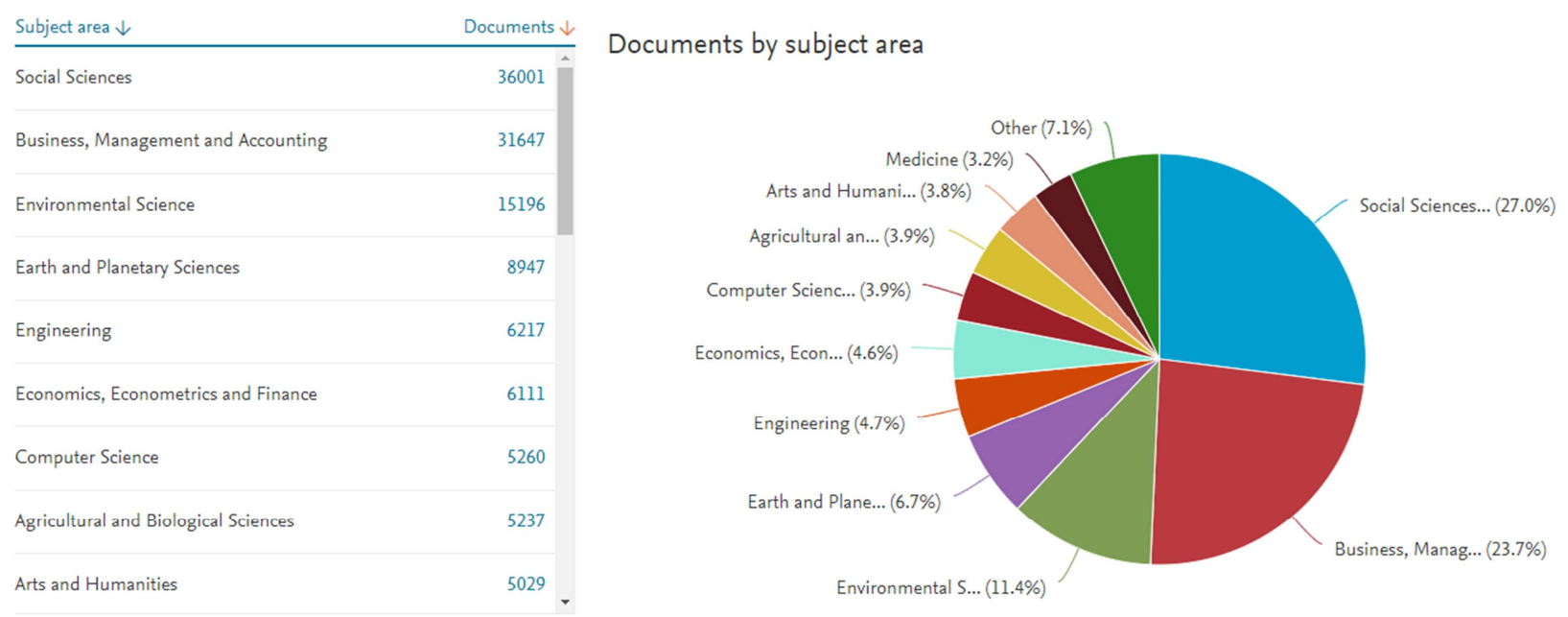

Figure 2. Publications on tourism by subject areas.

The published documents of Tourism go up to 75822 since the year 1947, being represented preferably by articles. Conferences have also been written, and books, among others. (Figure 3 )

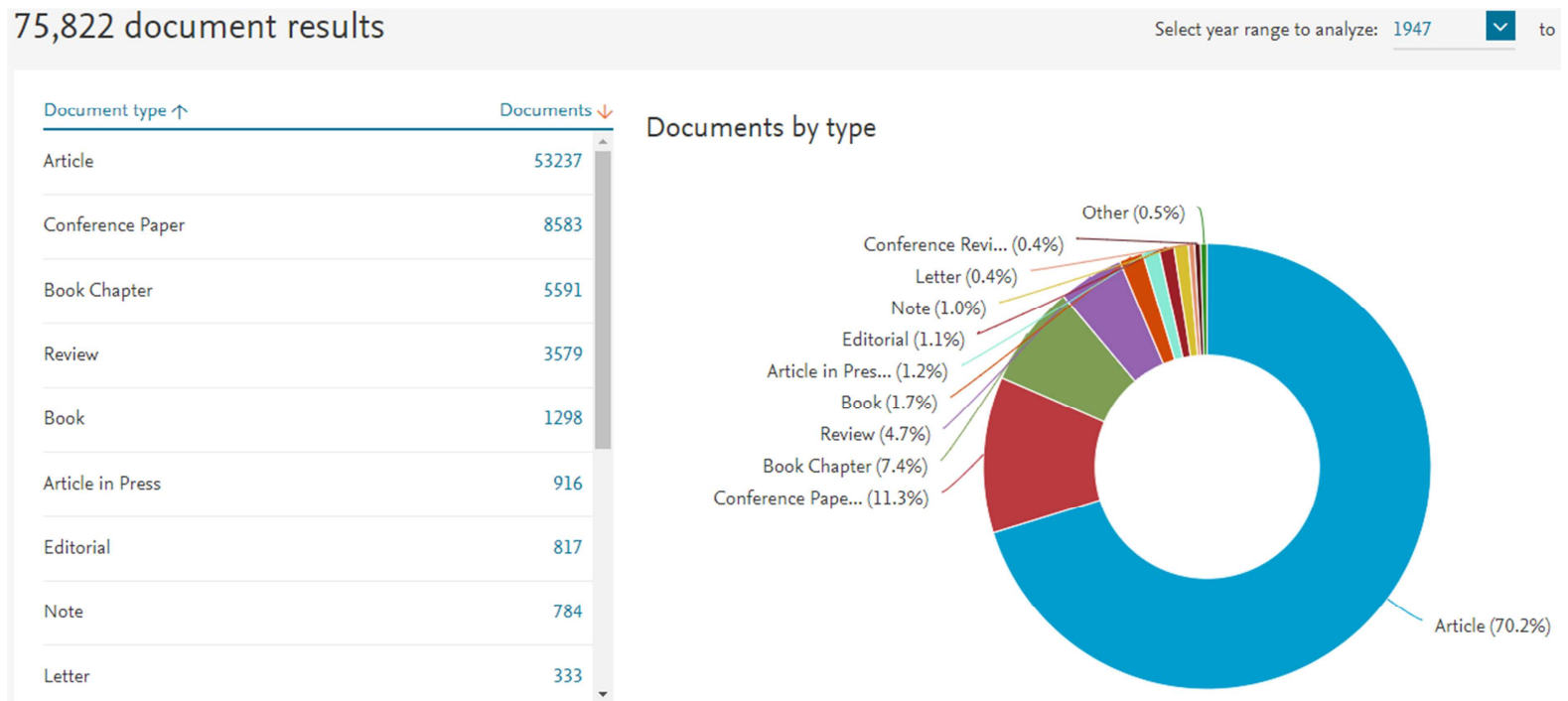

Figure 3. Publications on tourism by documents type.

In the period from 1947 up to now, about 2842 documents of tourist administration have been published, being this the developed topic. (Figure 4)

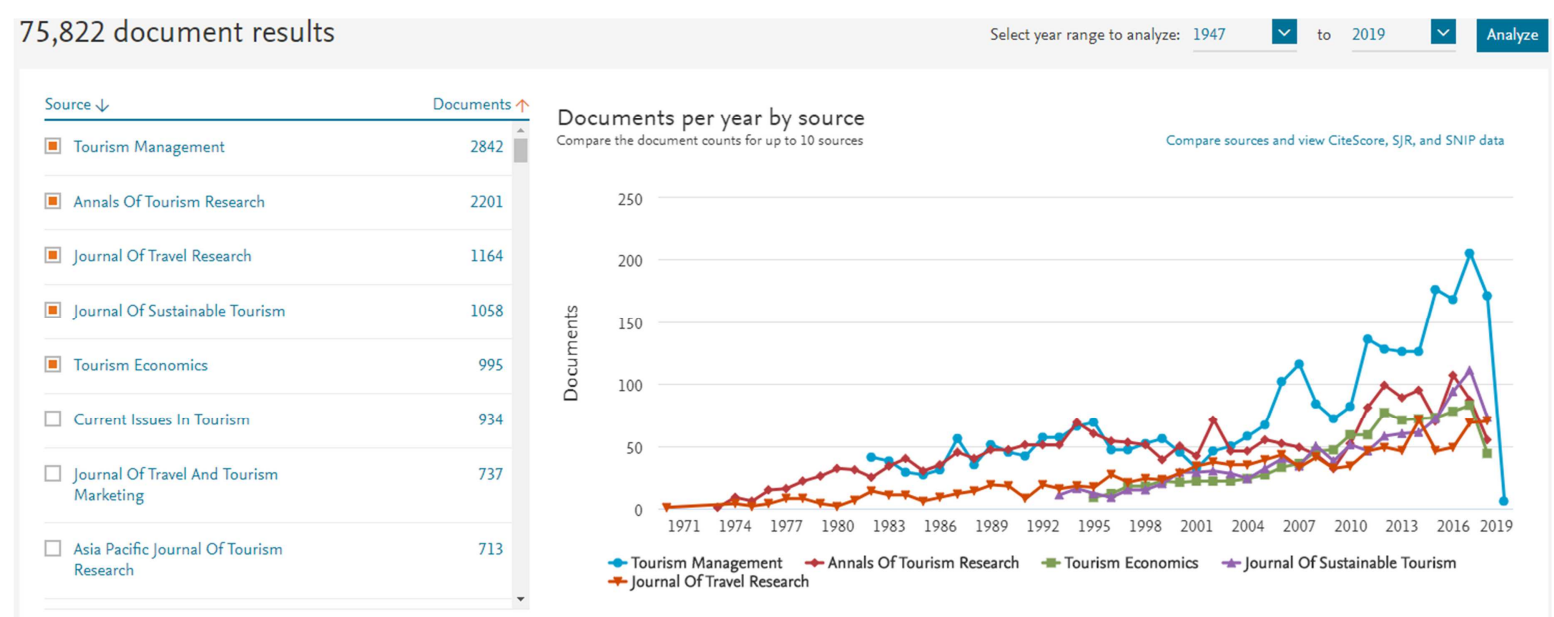

Figure 4. Tourism publications by year and source. 
The territories with a significant economic development are those that have approached the topic of the Tourism with more depth, like it represents the following chart. United States is the one that takes the leading with 12256 documents. (Figure 5)

\begin{tabular}{lr} 
Country/Territory & Documents $\downarrow$ \\
\hline$\square$ United States & 12256 \\
$\square$ United Kingdom & 8029 \\
$\square$ Australia & 6221 \\
$\square$ China & 5745 \\
$\square$ Spain & 4023 \\
$\square$ Canada & 3011 \\
$\square$ Italy & 2566 \\
$\square$ Germany & 2114 \\
$\square$ New Zealand & 1902.
\end{tabular}

Documents by country or territory

Compare the document counts for up to 15 countries/territories

Figure 5. Publications on tourism by country or territory.

It was also obtained the affiliations that have published about Tourism in an upward way what is evidenced in the following graph (Figure 6):

\begin{tabular}{lc}
\hline Amtliation $\uparrow$ & Uocuments $\downarrow$ \\
\hline Hong Kong Polytechnic University & 1196 \\
$\square$ Griffith University & 829 \\
$\square$ University of Queensland & 783 \\
$\square$ School of Hotel and Tourism \\
$\begin{array}{l}\text { Management, The Hong Kong } \\
\text { Polytechnic University }\end{array}$ \\
$\square$ James Cook University, Australia \\
$\square$ University of Surrey \\
$\square$ University of Otago \\
$\square$ Chinese Academy of Sciences
\end{tabular}

Documents by affiliation

Compare the document counts for up to 15 affiliations

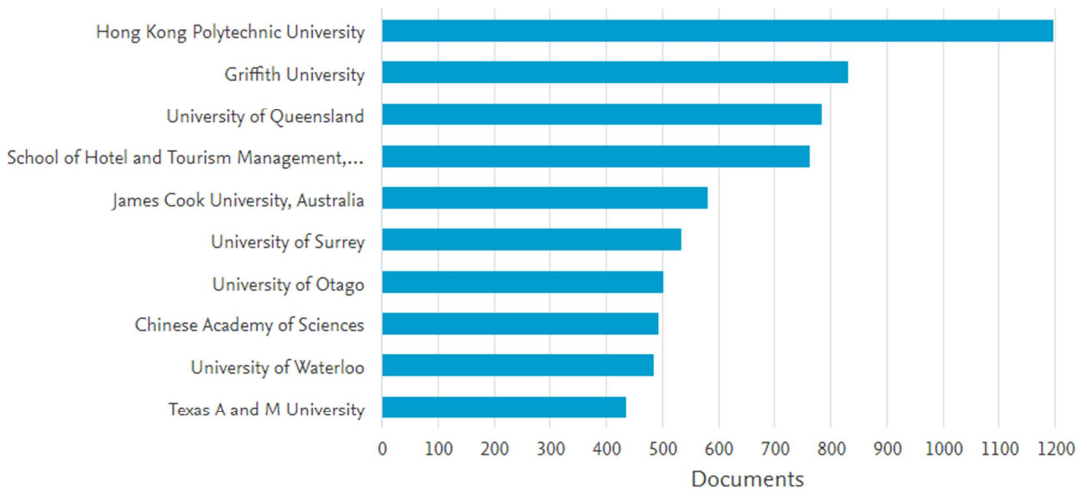

Figure 6. Publications on tourism by affiliation.

The authors that more impact has had in the topic are also detailed and the quantity of documents published by each one. (Figure 7)

\begin{tabular}{lr} 
Author $\uparrow$ & Documents $\downarrow$ \\
\hline$\square$ Law, R. & 252 \\
$\square$ Hall, C.M. & 228 \\
$\square$ Ryan, C. & 153 \\
$\square$ Wall, G. & 142 \\
$\square$ Prideaux, B. & 108 \\
$\square$ Saayman, M. & 108 \\
$\square$ Song, H. & 108 \\
$\square$ Dwyer, L. & 105 \\
$\square$ McKercher, B. & 105
\end{tabular}

Documents by author

Compare the document counts for up to 15 authors

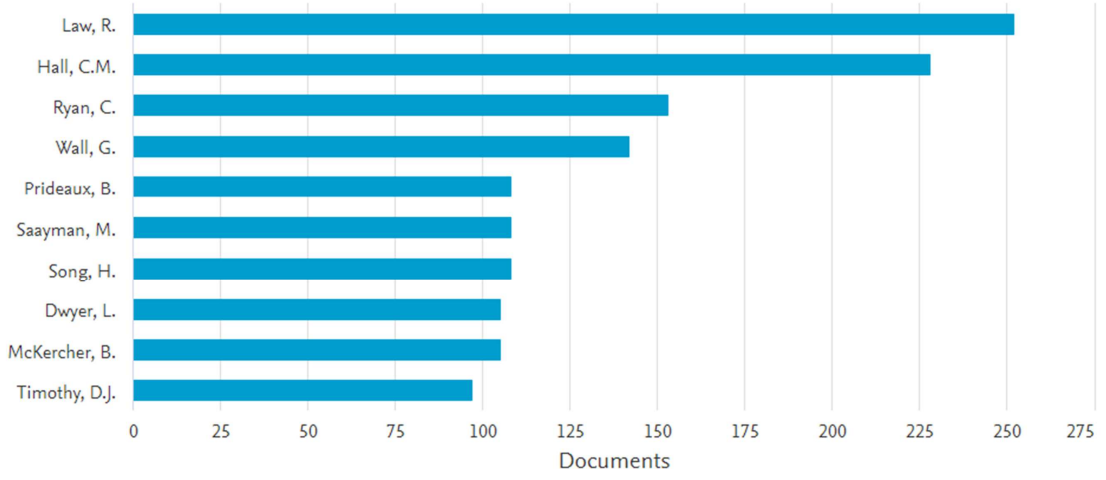

Figure 7. Publications on tourism by numbers of authors. 
In the following graph it is shown the scientific production represented by year of tourist product. The year 2017 was that of more production with 1007 documents, followed by 2016 and 2015. It is significant to point out that both slopes are increased in a remarkable way starting from 1999, but it exists a descent in the present year still unconcluded. However, there are publications corresponding to the year 2019. (Figure 8)

\begin{tabular}{lr} 
Year $\downarrow$ & Documents $\uparrow$ \\
\hline 2019 & 13 \\
2018 & 1007 \\
2017 & 1423 \\
2016 & 1236 \\
2015 & 1099 \\
2014 & 986 \\
2013 & 817 \\
2012 & 765 \\
2011 & 645.
\end{tabular}

Documents by year
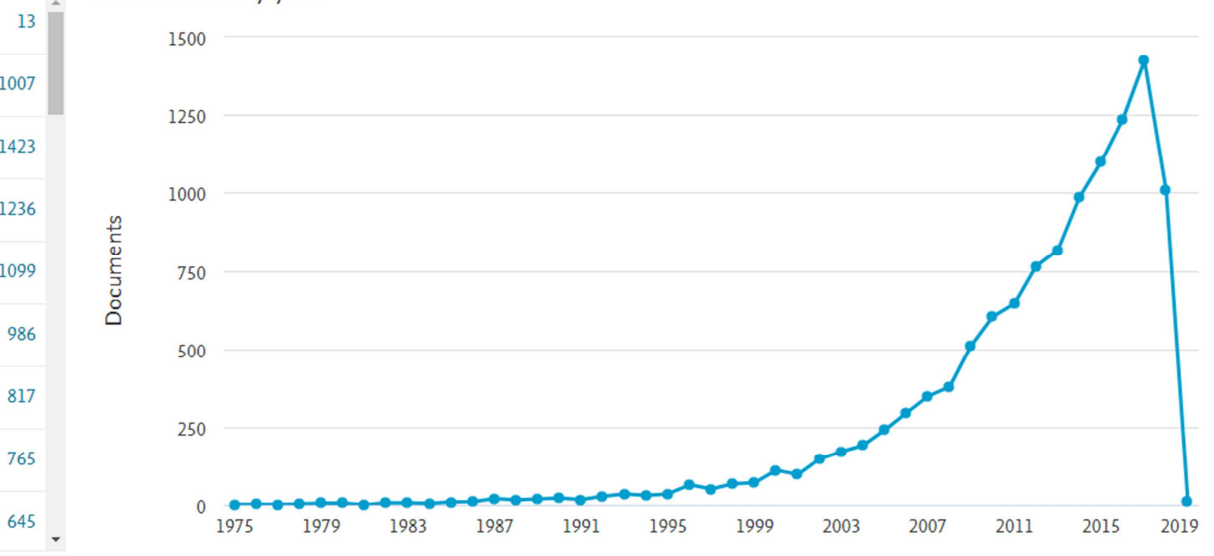

Figure 8. Scientific tourist production per year.

Since 1975 until the present time, 11614 documents of Tourism have been published, standing out the biggest figure in the topic of upward tourist administration to 845 documents. Starting from the year 2005 the magazine Asia Pacific was the avantgarde one in the topic of the tourism, followed by the Magazine of investigation of trips and Magazine of marketing of trips and tourism. (Figure 9)

11,614 document results

Select year range to analyze: 1975

$\checkmark$ to 2019

$\checkmark$ Analyze

\begin{tabular}{lr} 
Source $\downarrow$ & Documents $\uparrow$ \\
\hline$\square$ Tourism Management & 845 \\
$\square$ Journal Of Travel Research & 355 \\
$\square$ Annals Of Tourism Research & 343 \\
$\square$ Journal Of Travel And Tourism \\
Marketing \\
$\begin{array}{l}\text { Asia Pacific Journal Of Tourism } \\
\text { Research }\end{array}$ \\
$\square$ Journal Of Sustainable Tourism \\
$\square$ Current Issues In Tourism \\
$\square$ Tourism Economics \\
\end{tabular}

Documents per year by source

Compare the document counts for up to 10 sources $\quad$ Compare sources and view CiteScore, SJR, and SNIP data

Figure 9. Tourist products publication according to documents per year by source.

By means of a comparison carried out to documents published by 15 authors, they are recognized as the most outstanding to: Law, R. with 81 publications, followed by Saayman, M. with 55 and Ryan, C. with 51; which is shown in the diagram that is shown next. (Figure 10) 
11,614 document results

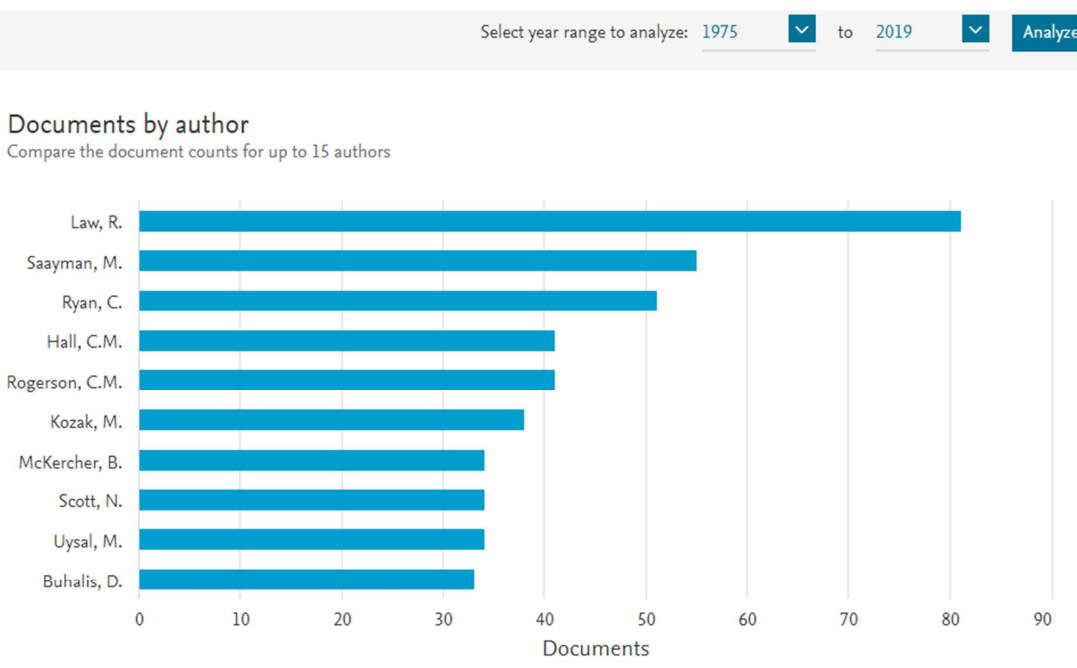

Figure 10. Tourist products documents by author.

The universities that have had an important relevance in the topic of tourist product are detailed next (Figure 11):

1. Polytechnic university of Hong Kong with 357 documents.

2. Hotel Management School and Administration of the Tourism, in the Polytechnic University of Hong Kong with 246 documents.

3. University of Griffith in Ireland, with 207 documents.

4. University of Queensland in Australia with 173 documents.

5. University of Bournemouth and Surrey in England with
129 and 125 documents, respectively.

6. University of Purdue in United States with 119 documents.

7. James Cook University, in Australia with 114 documents.

It can be assumed that the biggest quantity in publications is in the countries of the first world and with a high economic development which influences in the demand and tourist offer and in consequence in the investigations on the thematic.

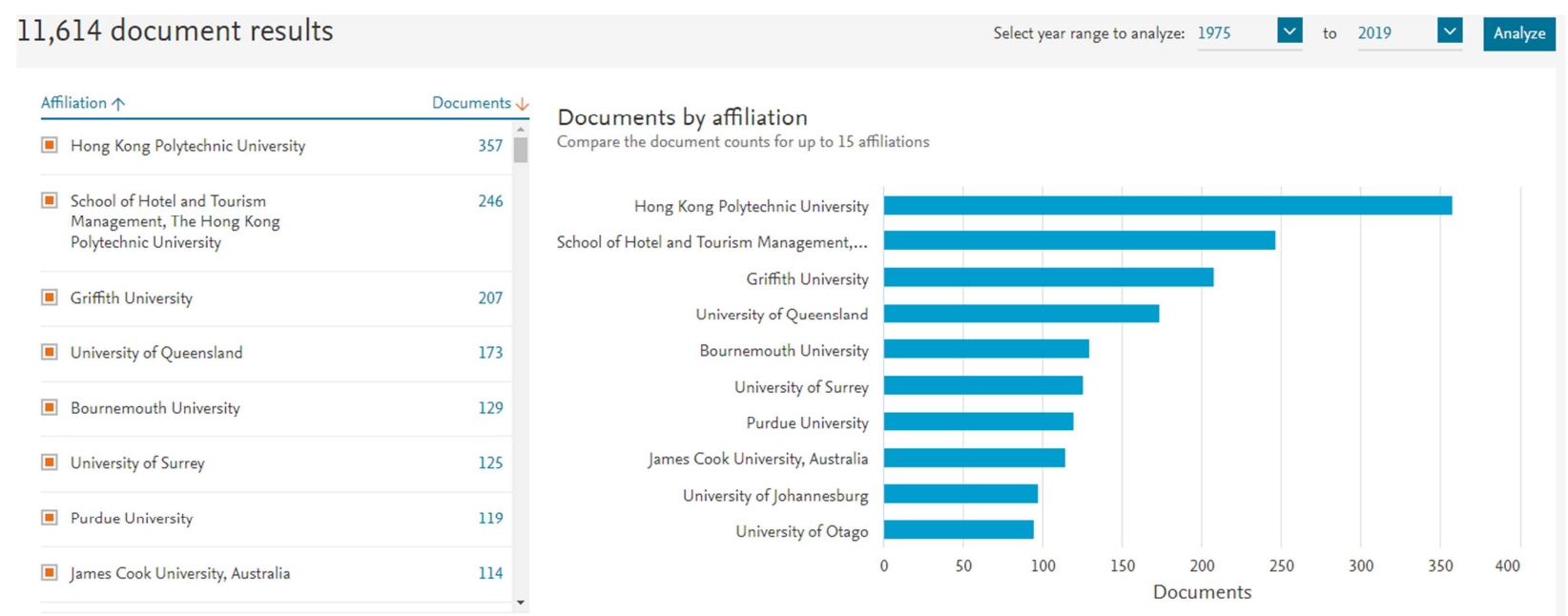

Figure 11. Universites' publications on tourist products by affiliation.

With relationship to the countries that more publications have carried out in this topic is in the first place the United States with 1855 documents, followed by United Kingdom with 1384, besides Australia with 1235 documents. Followed by other territories, as it is shown in the following chart. (Figure 12) 


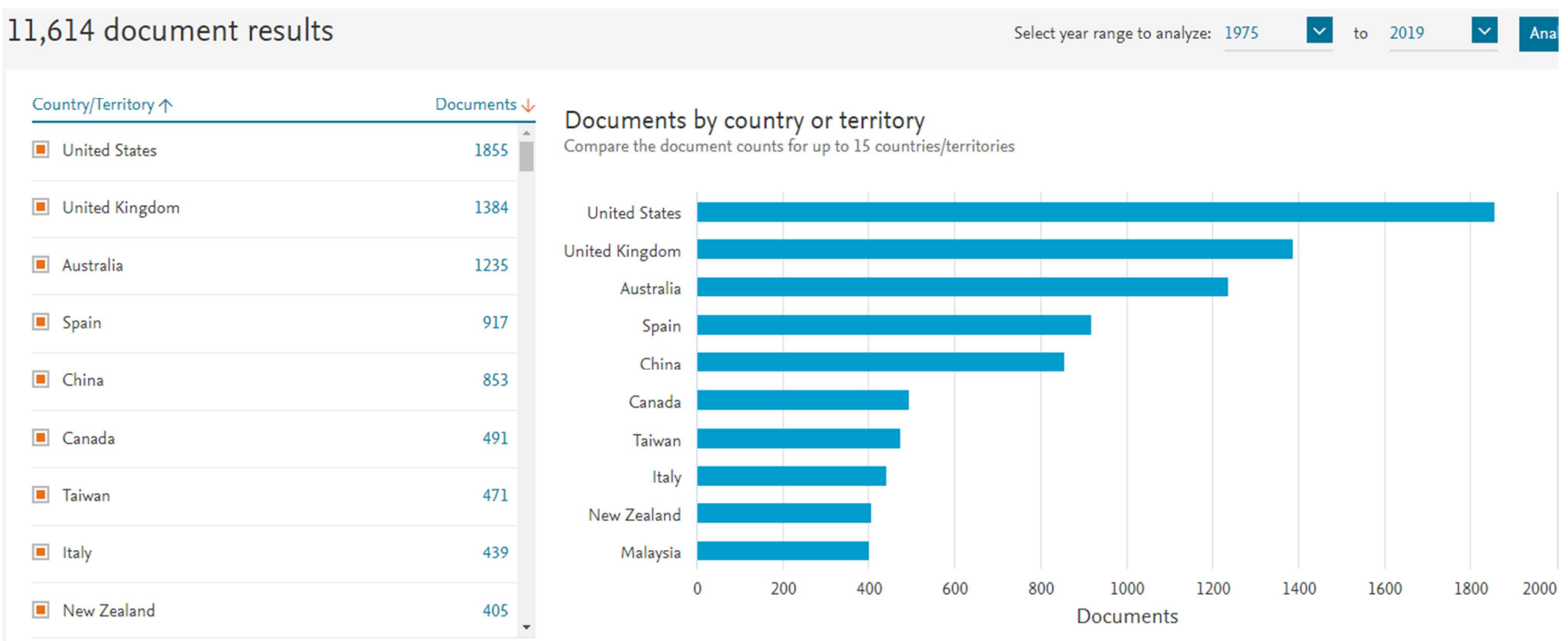

Figure 12. Outstanding countries publishing tourist products.

In the period of reference, the document type that has been more published is the articles of tourist product, which represents $79 \%$ of the total; 809 chapters of books also exist, 792 printed conferences, 442 critics articles, among others that approach this topic, like it is represented in the following graph (Figure 13):
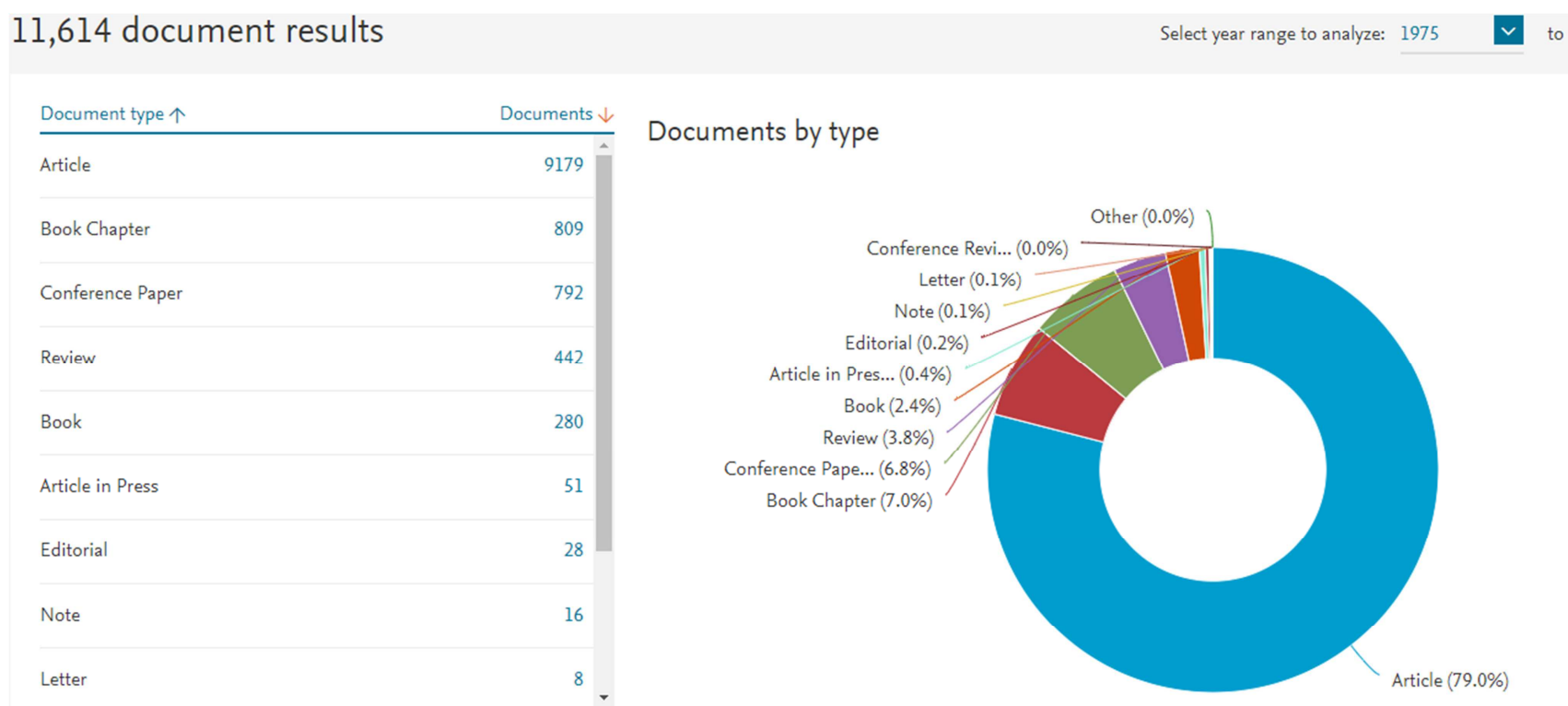

Figure 13. Documents type published the most on tourist products.

It was also determined the written documents of tourist product, for thematic area, being demonstrated that they are the economic sciences and administration those more referenced to the topic, and in which my investigation design is framed; what is reflected in the graph that is shown next (Figure 14):

1. Business, administration and accounting with 7872 documents.

2. Social sciences, 6143 documents.

3. Environmental science with 1524 documents.
4. Economy, econometrics and finances, 1209 documents.

5. Computing, 665 documents.

6. Terrestrial and planetary sciences with 654 documents.

7. Engineering with 524 documents.

8. Arts and Humanities, 509 documents.

9. Agricultural and biological sciences with 434 documents.

All this shows that tourism is a science that generates the integration of all the other ones and the participation of these for its integrative character. 


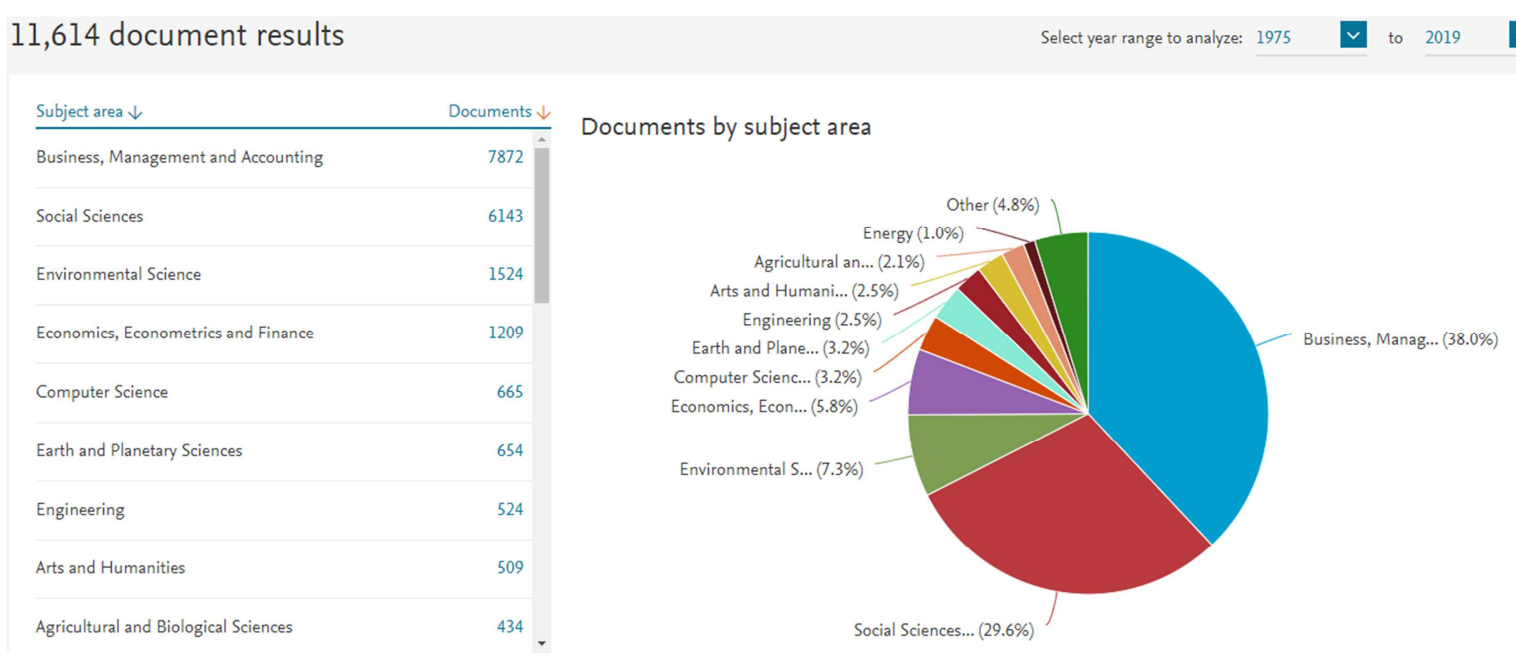

Figure 14. Published documents on tourist products by areas.

\section{Conclusions}

After an in-depth analysis it can be inferred that researches within the scope of tourism in global terms and specifically those related to analysis-oriented turist products came out to be wide, diverse and pertinets. As it can be noticed such researches are objects of different and complementary visions from several scientific knowledge areas. Likewise, it was revealed that such researches are quite often abundant in highly social and economic developed countries. At the same time, tourist destinations stand themselves as a byproduct of this very same developement that trigger or motivate the realization of these investigationsn in their operative working. The generated information by this research can be used as a pedestal by researchers willing to demonstrate the pertinence or possible viability of unique potentialities to implement in tourist affairs. It responds to the volume of publications taht are produced to cover this issue, which is a highlighted signal. Equally important, there are varied standpoints on this theme. Thus, the outcomes can serve as an information income for students and professors dedicated to the analysis of the tourist phenomenon as an important social, cultural and economic manifestation that brings about a move in the financial flow, interchanges and cultural modifications among other impacts.

\section{References}

[1] Chaviano, E. L., \& Aro, Y. H. (2007). Procedimiento para el diseño de un producto turístico integrado en Cuba. Teoría y Praxis, 161-174.

[2] Santesmases, M. (1993). Marketing: conceptos y estrategias ( $2^{\mathrm{a}}$ ed.). Madrid: Pirámide.

[3] Mazur, G. (2002). Despliegue de la función de calidad.

[4] Kotler, P. (1992). Dirección de marketing. Madrid: Prentice Hall.
[5] Fernández, R. M. (2003). Fundamentos del turismo. La Habana: EAEHT.

[6] SERNATUR. (2015). Manual Paso a paso para el Diseño de Productos Turísticos integrados. Santiago de Chile: Ministerio de Economía, Fomento y Turismo.

[7] Eduardo, C. C. (2015). METODOLOGÍA PARA DESARROLLAR PRODUCTOS TURÍSTICOS - CASO DE. Memoria del IX Congreso de la Red Internacional de Investigadores en Competitividad, 96-109.

[8] De la Riva, J., Ibarra, P., Montorio, R., \&Rodrigues, M. (2015). Rutas turísticos-culturales e itinerarios culturales como productos turísticos: reflexiones sobre una metodología para su diseño y evaluación. Análisis espacial y representación geográfica: innovación y aplicación, 463-471.

[9] Saravia, M. d., \& Muro, M. N. (2016). Productos turísticos. Metodología para su elaboración. revista de ciencias sociales, segunda época, 53-78.

[10] Aleksandrov, K. (2016). Opportunities for creation of integrated tourism product (following the example of the municipality of Velingrad). Management, Economic Engineering in Agriculture and Rural Development, 3.

[11] Chang, H.-L., Chou, Y.-C., Wu, D.-Y., \& Wu, S.-C. (2018). Will firm's marketing efforts on owned social media payoff? A quasi-experimental analysis of tourism products. Decision Support Systems, 13-25.

[12] McKercher, B. (2016). Towards a taxonomy of tourism products. Tourism Management, 196-208.

[13] Pyke, S., Hartwell, H., Blake, A., \& Hemingway, A. (2016). Exploring well-being as a tourism product resource. Tourism Management, 94-105.

[14] Tjahyanto, A., \&Sisephaputra, B. (2017). The Utilization of Filter on Object-based Opinion Mining in Tourism Product Reviews. Procedia Computer Science, 38-45.

[15] Peña, L. J. (2012). Análisis bibliométrico sobre la producción científica archivística en la Red de Revistas Científicas de América Latina y el Caribe (Redalyc) durante el período 2001-2011. Biblios.

[16] Chaviano, O. (2004). Algunas consideraciones teóricoconceptuales sobre las disciplinas métricas. Acimed. 